\title{
Impact of germination conditions on antioxidant properties and protein content in lentils (Lens culinaris) of Ukrainian cultivars
}

\author{
Iryna Yasinska, Viktoriia Ivanova
}

\section{National University of Food Technologies, Kyiv, Ukraine}

Keywords:

Lentil

Germination

Antioxidant

Protein

Light

Article history:

Received

10.06.2018

Received in

revised form

29.10.2018

Accepted

03.12 .2018

\section{Corresponding author:}

Iryna Yasinska

E-mail:

yasinskaya.ira@ gmail.com

DOI:

$10.24263 / 2310$

1008-2018-6-2-7

\section{Abstract}

Introduction. Changes in the free radical scavenging activity, the yield of phenolic compounds, ascorbic acid and proteins content in lentil seeds of two Ukrainian cultivars were determined during the germination period under different light conditions.

Materials and methods. Were studied the effect of germination on two Ukrainian varieties of lentils namely Luganchanka and Svitanok. The total phenolics content (TPC) in samples was determined using Folin-Ciocalteu assay, the ascorbic acid level was determined by a colorimetric assay, free radical scavenging activity was elucidated using DPPH assay, changes of proteins content were found out according to Kjeldahl's method.

Results and discussion. Results of the research have shown that during germination in seeds highly increased levels of the total phenolics, ascorbic acid and free radical scavenging activity, especially under day-night photoperiod light conditions. The proteins content in seeds at the end of germination was a little lower comparing with ungerminated seeds under both of light conditions.

The highest rise of TPC was fixed in lentils var. Luganchanka on the $3-4^{\text {th }}$ germination day. The increase was about $65 \%$.

A similar situation was with changing of ascorbic acid level. It was higher 6 times if compare germinated and ungerminated samples of lentils var. Luganchanka, obtained under day-night conditions.

The antiradical activity of germinated seeds was the highest at the end of the germination process. However, germinating after the $5^{\text {th }}$ day under studied conditions is unacceptable, because the rotting of sprouts happened. The lowest increase near $60 \%$ had germinated materials of var. Svitanok that were obtained in dark conditions. The highest increase of antioxidant activity was near 550\% in samples var. Luganchanka after germinating in day-night conditions.

Conclusions. Our results demonstrate that germinated lentil seeds both cultivars have advantages over nongerminated and can be useful in functional food technologies. 


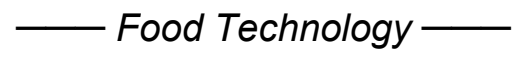

\section{Introduction}

Legumes play an important role in human nutrition in many diets. Lentil is one of the most valuable species of legumes. Its seeds are an excellent source of protein, rich in important vitamins, minerals, dietary fiber. According to recent studies [1-5], lentil could be considered as a prophylactic and therapeutic functional ingredient due to it sizable content of essential micronutrients as well as phytochemicals. These components can provide antiinflammatory, hepatoprotective, antioxidant effects, lead to the prevention of heart diseases, diabetes, DNA damage and other disorders $[4,5]$.

Germination is inexpensive and effective bioengineering process that can highly increase the nutritional value of lentil seeds by intensive synthesis of bioactive compounds $[6,7]$, desirable changes in the nutrient availability [8] and decreasing of anti-nutritional components (phytic acid, tannins) [9]. During the germination period, the content of lowmolecular weight antioxidants such as polyphenols [10,11], ascorbic acid, tocopherols grows up, that provides increasing the antioxidant properties of seeds [7,12]. The qualitative and quantitative composition of the functional components in germinated seeds depends on many variables, which includes soaking time, humidity, temperature, germination time, presence of chemical elicitors $[13,14]$ and other biotic and abiotic factors $[15,16]$. Numerous studies have shown that the content of the synthesized components also depends on seeds variety and places of plant cultivation [17].

The aim of our study was to determine the dynamic of free radical scavenging activity changes, the yield of total phenolic compounds and ascorbic acid in lentils of Ukrainian cultivars depending on the germination time, light conditions (dark or day-night photoperiod) and the plant variety. Also changes of the crude protein content, as one of the main component of lentil seeds were monitored.

\section{Materials and methods}

Raw materials of two Ukranian varieties of lentil (Lens culinaris) namely Luganchanka and Svitanok were used in the study. Plants had been grown under the same environmental conditions in the Mykolaiv region, Ukraine. Seeds were collected during summer and autumn months of 2014 and handpicked to ensure usage of unbroken material.

Germination was done according to procedure written below. Dry seeds were cleaned and disinfected with $1 \%$ potassium hypochlorite for $5 \mathrm{~min}$, washed with distilled water to neutral $\mathrm{pH}$, soaked in distilled water for $4 \mathrm{~h}$ at $20{ }^{\circ} \mathrm{C}$ and placed in Petri dishes with an adsorbent paper. Seeds were germinated for 5 days at $20^{\circ} \mathrm{C}$ in two different light conditions: in dark (D) and day-night (DN) (day $-16 \mathrm{~h}$, night $-8 \mathrm{~h}$ ) photoperiod. Seeds were kept moist by spraying them with distilled water. The germination process was done in triplicate. The percentage of germinated seeds was evaluated.

Experimental parameters of seeds were assayed every day during the period of germination. Before that, seeds were air-dried at $35^{\circ} \mathrm{C}$ for $8 \mathrm{~h}$ and milled.

The total phenolics content (TPC) of extracts was determined using Folin-Ciocalteu assay [18]. Seeds and sprouts were subjected to extraction using $70 \%$ aqueous-ethanolic solution. The ratio of raw material : extractant was 1:10. The extraction process had been continued for $4 \mathrm{~h}$ at room temperature with intense shaking. Extracts were centrifuged at $4000 \mathrm{rpm}$ for $15 \mathrm{~min}$ and filtered through the filter paper. Supernatants were used for further analysis.

Ungerminated seeds were prepared as noted above to serve as a control. 


\section{— Food Technology -}

Briefly, $0.1 \mathrm{ml}$ of the extract or ultra-pure water or gallic acid standard solution (0-0.2 $\mathrm{mg} / \mathrm{ml}$ ) was diluted with $1 \mathrm{ml}$ of ultra-pure water, $0,1 \mathrm{ml}$ of Folin-Ciocalteu reagent and left standing at room temperature for $5 \mathrm{~min}$. Then $2 \mathrm{ml}$ of $2 \%$ sodium carbonate was added and the mixture was incubated at room temperature for $20 \mathrm{~min}$. The absorbance was measured at $765 \mathrm{~nm}$ with the spectrophotometer BioMate 5 (Thermo electron corporation, USA). Gallic acid solution was used for the construction of a calibration curve as a standard. The total phenolic content was expressed as mg gallic acid equivalent (GAE) per $100 \mathrm{~g}$ dry weight of seeds.

Ascorbic acid was extracted with ultra-pure water acidified 2\% meta-phosphoric acid according to our latest procedure [19] and determined by a colorimetric assay [20].

Free radical scavenging activity of aqueous and $70 \%$ aqueous-ethanolic extracts was determined using DPPH assay based on the activity of the stable 1,1-diphenyl-2-2picrylhydrazyl (DPPH) free radical as described by Brand-Williams et al. [21].

Briefly, the alcoholic solution of DPPH $(1.8 \mathrm{ml})$ was added to $0.2 \mathrm{ml}$ of extracts obtained from plant materials. Samples were incubated in the dark place at room temperature for 30 min. The decrease in absorbance was measured at $517 \mathrm{~nm}$ by UV-VIS spectrophotometer for all samples. The absorbance of the DPPH radical solution without antioxidant was measured as the control (Ac). The percentage of inhibition of the DPPH radical by samples was calculated according to the equation:

$$
\% \text { Inhibition }=[(\text { Ac-As }) / A c] 100,
$$

where: Ac - absorbance of the control, As - absorbance of the solution of DPPH radical with extract or standard after the reaction.

Blank samples contained $1.8 \mathrm{ml}$ of ethanol and $0.2 \mathrm{ml}$ of plant extract; control sample contained $1.8 \mathrm{ml}$ of $0.04 \mathrm{mM}$ DPPH and $0.2 \mathrm{ml}$ of ethanol. The synthetic antioxidant ascorbic acid was used as a standard. Antiradical activity of samples was presented as ascorbic acid equivalent capacity and expressed as $\mathrm{mM}$ of the ascorbic acid equivalent (AAE) antioxidant capacity per $1 \mathrm{~g}$ of seeds dry weight (mM AAE/g DW).

Total nitrogen was determined according to Kjeldahl`s method [22]. Crude protein was calculated as Nitrogen content multiply on 6,25.

Experimental results were expressed as mean \pm standard deviation of three replicates. Where applicable, the data were subjected to one-way analysis of variance (ANOVA) and the differences among samples were determined using the statistical analysis system Statgraphics. P-value of $<0.05$ was regarded as significant.

\section{Results and discussion}

The dynamic of the lentil sprouts length changing were evaluated under different germination conditions (Table 1).

Sprouts that had been obtained under day-night photoperiod light conditions were significantly longer than sprouts had grown in the dark. They were stronger and thicker. Their green color was conditioned by the photosynthesis process.

The sprout's length of the var. Luganchanka and var. Svitanok under the same germination conditions did not differ significantly. 
Table 1

The length of sprouts grown under different conditions [mm]

\begin{tabular}{|c|c|c|c|c|}
\hline \multirow{2}{*}{ Germination day } & \multicolumn{4}{|c|}{ Lentil seeds varieties } \\
\cline { 2 - 5 } & \multicolumn{3}{|c|}{ Luganchanka } & \multicolumn{2}{c|}{ Svitanok } \\
\cline { 2 - 5 } & \multicolumn{4}{|c|}{ Light condition } \\
\cline { 2 - 5 } & $\mathrm{D}$ & $\mathrm{DN}$ & $\mathrm{D}$ & $\mathrm{DN}$ \\
\hline 1 & $3.5 \pm 0.15$ & $4 \pm 0.2$ & $3 \pm 0.18$ & $4 \pm 0.22$ \\
\hline 2 & $13 \pm 0.85$ & $38 \pm 1.8$ & $11.5 \pm 0.7$ & $32 \pm 1.65$ \\
\hline 3 & $19 \pm 1.05$ & $52 \pm 3.5$ & $18 \pm 1.0$ & $50 \pm 3.8$ \\
\hline 4 & $25 \pm 1.4$ & $68 \pm 4$ & $24 \pm 1.5$ & $65 \pm 4$ \\
\hline 5 & $34 \pm 1.8$ & $97 \pm 5.5$ & $32 \pm 2$ & $89 \pm 4.5$ \\
\hline
\end{tabular}

After the $5^{\text {th }}$ day of germination under both of conditions, the rotting of sprouts happened. Therefore, germination after the $5^{\text {th }}$ day under these conditions is unacceptable.

Results have shown that under day-night photoperiod it occurs the increasing of the TPC level (Figure 1).

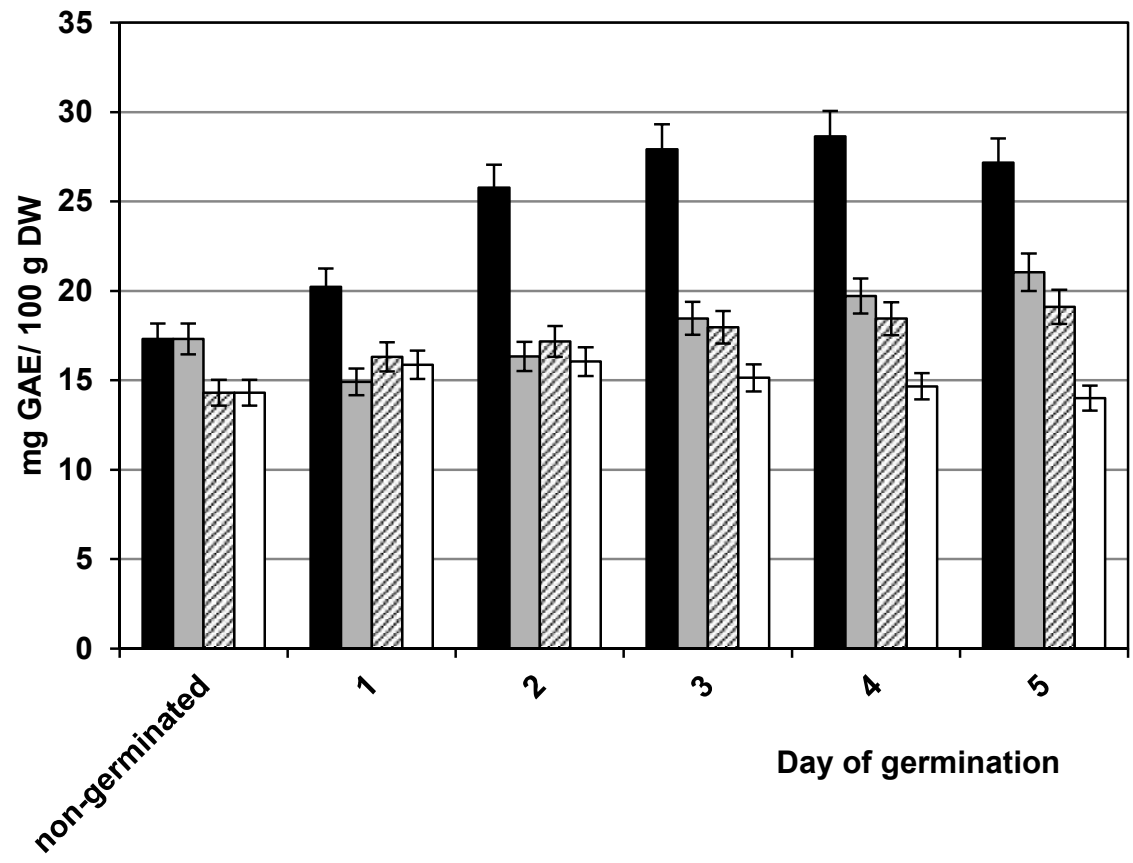

Evar. Luganchanka DN

घvar. Svitanok DN 口var. Luganchanka D

$\square$ var.Svitanok D

Figure 1. The total phenolics content of germinated seeds obtained under different light conditions (D, DN) 
The visible increase of TPC during germination time had lentil sprouts var. Luganchanka, which were growing under the day-night photoperiod condition. The maximum value of total phenolics in this seeds was on the $3-4^{\text {th }}$ germination days and it was higher than in ungerminated material on $65 \%$. Obtained results are in agreement with those were given in similar studies [10,23]. Sprouts of lentil seeds var. Svitanok demonstrated a decrease of TPC in darkness and increase under the day-night photoperiod condition.

Investigated samples, which were germinated under the day light, demonstrated more significant increase of the TPC level in comparison to sprouts obtained in dark conditions. This can be explained by the fact that different light conditions influence on activating prolinlinked phentose phosphate and shikimate pathways for phenols synthesis [24].

In the similar studies [25] were shown that the level of TPC in lentil sprouts during germination period was in a steady decline. The distinction in results can be explained by different cultivars and environment conditions in regions of cultivation of plants. On the other hand, authors didn't take into consideration changes of moisture content in the investigating samples during germination.

As in the case of polyphenols, better production of ascorbic acid was under the daynight photoperiod condition that in the dark. But in contrast to polyphenols a maximal increase of the ascorbic acid content was observed on the $1^{\text {st }}$ day of germination (Figure 2).

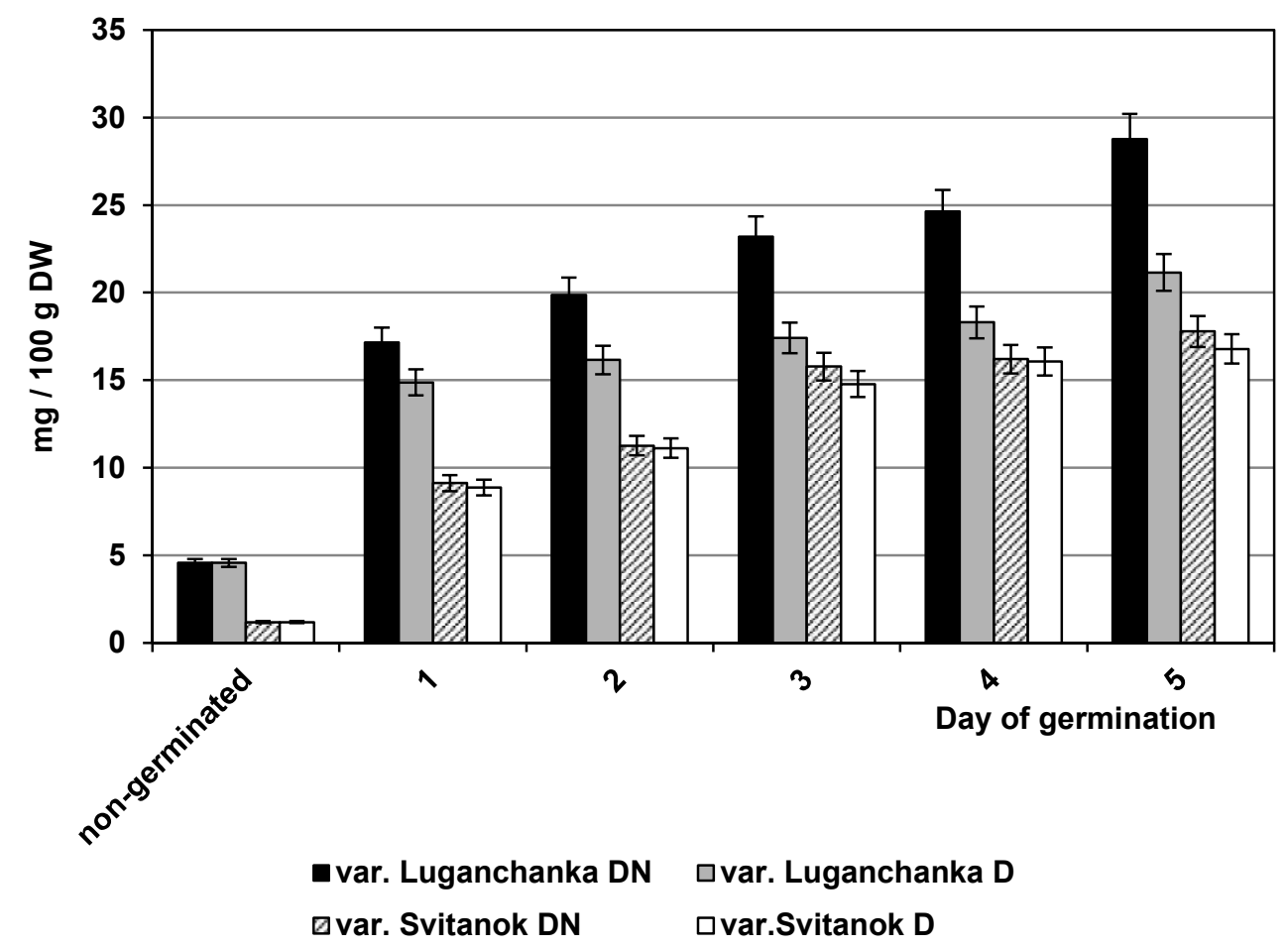

Figure 2. Ascorbic acid content in samples obtained under different light condition (D, DN) 


\section{— Food Technology -}

The ascorbic acid content in sprouts of var. Luganchanka was significantly higher than in var. Svitanok. Also the differences in the vitamin C content in materials prepared under the darkness and day-night conditions in var. Luganchanka was differ significantly, however, this indexes for var. Svitanok was not considerable.

The research of two types of extracts from lentil sprouts (aqua (A) and aqueousethanolic (AE)) on their antiradical activity has showed dynamics similar to results previously described (Table 2).

Table 2

Free radical scavenging activity of aqueous-ethanolic and aqueous extracts of lentil seeds [mM AAE/g DW]

\begin{tabular}{|c|c|c|c|c|c|c|c|c|}
\hline \multirow{6}{*}{$\begin{array}{c}\text { Germination } \\
\text { day }\end{array}$} & \multicolumn{8}{|c|}{ Varieties of lentil seeds } \\
\hline & \multicolumn{4}{|c|}{\begin{tabular}{l|l} 
Luganchanka & \\
\end{tabular}} & \multicolumn{4}{|c|}{ Svitanok } \\
\hline & \multicolumn{8}{|c|}{ Light condition } \\
\hline & \multicolumn{2}{|c|}{$\mathrm{D}$} & \multicolumn{2}{|c|}{$\mathrm{DN}$} & \multicolumn{2}{|c|}{$\mathrm{D}$} & \multicolumn{2}{|c|}{$\mathrm{DN}$} \\
\hline & \multicolumn{8}{|c|}{ Types of extracts from lentil seeds and sprouts } \\
\hline & $\mathrm{AE}$ & A & $\mathrm{AE}$ & A & $\mathrm{AE}$ & A & $\mathrm{AE}$ & A \\
\hline 1 & $\begin{array}{l}34,85 \\
\pm 1,02\end{array}$ & $\begin{array}{c}19,91 \\
\pm 0,86\end{array}$ & $\begin{array}{l}42,56 \\
\pm 2,61\end{array}$ & $\begin{array}{l}25,56 \\
\pm 1,08\end{array}$ & $\begin{array}{l}22,18 \\
\pm 1,89\end{array}$ & $\begin{array}{l}11,87 \\
\pm 0,57\end{array}$ & $\begin{array}{l}23,45 \\
\pm 1,09\end{array}$ & $\begin{array}{c}14,93 \\
\pm 0,66\end{array}$ \\
\hline 2 & $\begin{array}{l}39,43 \\
\pm 1,71\end{array}$ & $\begin{array}{l}27,99 \\
\pm 1,12\end{array}$ & $\begin{array}{l}54,33 \\
\pm 1,99\end{array}$ & $\begin{array}{l}34,19 \\
\pm 1,78\end{array}$ & $\begin{array}{l}24,56 \\
\pm 1,64\end{array}$ & $\begin{array}{l}14,12 \\
\pm 0,82\end{array}$ & $\begin{array}{l}25,11 \\
\pm 1,34\end{array}$ & $\begin{array}{l}19,61 \\
\pm 0,87\end{array}$ \\
\hline 3 & $\begin{array}{l}46,78 \\
\pm 2,89\end{array}$ & $\begin{array}{l}34,34 \\
\pm 1,76\end{array}$ & $\begin{array}{l}68,48 \\
\pm 1,66\end{array}$ & $\begin{array}{l}41,04 \\
\pm 2,27\end{array}$ & $\begin{array}{l}25,17 \\
\pm 1,34\end{array}$ & $\begin{array}{c}18,19 \\
\pm 0,63\end{array}$ & $\begin{array}{l}27,12 \\
\pm 1,08\end{array}$ & $\begin{array}{l}23,11 \\
\pm 1,32\end{array}$ \\
\hline 4 & $\begin{array}{l}54,61 \\
\pm 1,99\end{array}$ & $\begin{array}{l}38,12 \\
\pm 1,96\end{array}$ & $\begin{array}{l}76,92 \\
\pm 2,47\end{array}$ & $\begin{array}{l}52,47 \\
\pm 2,51\end{array}$ & $\begin{array}{l}23,52 \\
\pm 2,22\end{array}$ & $\begin{array}{l}21,16 \\
\pm 1,21\end{array}$ & $\begin{array}{l}30,02 \\
\pm 1,46\end{array}$ & $\begin{array}{l}27,08 \\
\pm 1,41\end{array}$ \\
\hline 5 & $\begin{array}{l}52,46 \\
\pm 2,13\end{array}$ & $\begin{array}{l}41,82 \\
\pm 2,26\end{array}$ & $\begin{array}{r}78,63 \\
\pm 3,49\end{array}$ & $\begin{array}{r}61,71 \\
\pm 2,87\end{array}$ & $\begin{array}{l}21,18 \\
\pm 2,79\end{array}$ & $\begin{array}{l}22,88 \\
\pm 1,02\end{array}$ & $\begin{array}{l}31,41 \\
\pm 1,62\end{array}$ & $\begin{array}{l}28,12 \\
\pm 1,22\end{array}$ \\
\hline $\begin{array}{c}\text { non- } \\
\text { germinated }\end{array}$ & $\begin{array}{l}31,79 \\
\pm 2,01 \\
\end{array}$ & $\begin{array}{l}11,07 \\
\pm 0,63 \\
\end{array}$ & $\begin{array}{l}31,79 \\
\pm 2,01 \\
\end{array}$ & $\begin{array}{l}11,07 \\
\pm 0,63 \\
\end{array}$ & $\begin{array}{l}19,77 \\
\pm 0,46 \\
\end{array}$ & $\begin{array}{c}6,67 \\
\pm 0,28 \\
\end{array}$ & $\begin{array}{l}19,77 \\
\pm 0,46 \\
\end{array}$ & $\begin{array}{c}6,67 \\
\pm 0,28 \\
\end{array}$ \\
\hline
\end{tabular}

During the germination process the antiradical activity level of sprouts gradually increased. As in the case with the content of phenols and ascorbic acid, higher activity had sprouts which were cultivated under the day-night photoperiod condition.

By contrast to changes in levels of low-molecular compounds with antioxidant activity, the level of crude protein content in sprouts was decline during the germination period (Table $3)$.

Bigger protein value had lentil of var. Luganchanka. On the $7^{\text {th }}$ germination day the protein content in both varieties were almost equal. Samples of lentil sprouts which were obtained in the darkness had a less the protein content.

Reducing of the protein amount during germination can be explained by their biotransformation in structural components of sprout and using as an energy source for growth. 


\section{Crude protein content in seeds and sprouts during germination $[\mathrm{g} / 100 \mathrm{~g}]$}

\begin{tabular}{|c|c|c|c|c|}
\hline \multirow{4}{*}{$\begin{array}{c}\text { Germination } \\
\text { day }\end{array}$} & \multicolumn{4}{|c|}{ Varieties of lentil seeds } \\
\hline & \multicolumn{2}{|c|}{ Luganchanka } & \multicolumn{2}{|c|}{ Svitanok } \\
\hline & \multicolumn{4}{|c|}{ Light condition } \\
\hline & $\mathrm{D}$ & $\mathrm{DN}$ & $\mathrm{D}$ & $\mathrm{DN}$ \\
\hline 1 & $33,87 \pm 0,89$ & $34,17 \pm 1,84$ & $28,96 \pm 1,21$ & $29,32 \pm 1,12$ \\
\hline 2 & $33,18 \pm 1,76$ & $32,13 \pm 0,99$ & $28,33 \pm 1,08$ & $29,06 \pm 1,33$ \\
\hline 3 & $31,96 \pm 1,12$ & $30,83 \pm 1,51$ & $28,01 \pm 1,67$ & $28,61 \pm 0,89$ \\
\hline 4 & $28,08 \pm 0,87$ & $29,77 \pm 0,78$ & $27,69 \pm 0,87$ & $28,08 \pm 1,19$ \\
\hline 5 & $27,87 \pm 0,81$ & $29,1 \pm 1,43$ & $27,17 \pm 1,33$ & $27,95 \pm 1,34$ \\
\hline $\begin{array}{c}\text { non- } \\
\text { germinated }\end{array}$ & $35,21 \pm 1,56$ & $35,21 \pm 1,34$ & $30,76 \pm 0,91$ & $30,76 \pm 1,64$ \\
\hline
\end{tabular}

\section{Conclusions}

Results have shown that the germination process provided increasing the content of total phenolics, ascorbic acid, and antiradical activity in investigated samples of lentil seeds.

Maximum values of experimental indexes were determined in seeds that were germinated under day-night light conditions.

During the germination period, the content of low molecular weight components with antioxidant activity was highly increased; whereas the content of such valuable component as protein was a little decreased. Definitely, germinated seeds can be used as sources of valuable components for preparing functional foods and supplements for oxidationassociated diseases prevention.

\section{References}

1. Arnoldi A., Zanoni C., Lammi C., Boschin G. (2015), The Role of Grain Legumes in the Prevention of Hypercholesterolemia and Hypertension, Critical Reviews in Plant Sciences, 34 (1-3), pp. 144-168.

2. Roy F., Boye J. I., Simpson B. K. (2010), Bioactive proteins and peptides in pulse crops: pea, chickpea and lentil, Food Research International, 43, pp. 432-442.

3. Xu B., K.C. Chang S. (2012), Comparative study on antiproliferation properties and cellular antioxidant activities of commonly consumed food legumes against nine human cancer cell lines, Food Chemistry, 134, pp. 1287-1296.

4. Xu B., K.C. Chang S. (2010), Phenolic Substance Characterization and Chemical and Cell-Based Antioxidant Activities of 11 Lentils Grown in the Northern United States, Agric. Food Chem., 58, pp. 1509-1517.

5. Padhi E. M. T., Liu R., Hernandez M., Tsao R., Ramdath D. D. (2017), Total polyphenol content, carotenoid, tocopherol and fatty acid composition of commonly consumed Canadian pulses and their contribution to antioxidant activity, Journal of Functional Foods, 38 (Part B), pp. 602-611.

6. Lin P., Lai H. (2006), Bioactive Compounds in Legumes and Their Germinated Products, $J$. Agric. Food Chem., , 54 (11), pp. 3807-3814. 


\section{- Food Technology -}

7. Huang X., Cai W., Xu B. (2014), Kinetic changes of nutrients and antioxidant capacities of germinated soybean (Glycine max L.) and mung bean (Vigna radiata L.) with germination time, Food Chemistry, 143, pp. 268-276.

8. Gawlik-Dziki U., Świeca M. (2011), Sprouts of selected plants as a source of bioavailable antioxidants and lipoxygenase inhibitors, Annales Univ. M. CurieSkłodowska Lublin - Polonia. Sectio DDD, 8 (3), pp. 161-168.

9. Mwikya S. M., Camp J. V., Rodriguez R., Huyghebaert A. (2001), Effects of sprouting on nutrient and antinutrient composition of kidney beans (Phaseolus Vulgaris var. Rose coco), European Food Research and Technology, 212 (2), pp. 188-191.

10. Cevallos C., Cisneros-Zevallos L. (2010), Impact of germination on phenolic content and antioxidant activity of 13 edible seed species, Food Chemestry, 119, pp. 14851490.

11. Pająk P., Socha R., Gałkowska D., Rożnowski J., Fortuna T. (2014), Phenolic profile and antioxidant activity in selected seeds and sprouts, Food Chemistry, 143, pp. 300 306.

12. Ghiassi Tarzi B., Gharachorloo M., Baharinia M., Mortazavi S.A. (2012), The Effect of Germination on Phenolic Content and Antioxidant Activity of Chickpea, Iran J Pharm Res., 11 (4), pp. 1137-43.

13. Dueñas M., Martínez-Villaluenga C., I. Limón R., Peñas E., Frias J. (2015), Effect of germination and elicitation on phenolic composition an bioactivity of kidney beans, Food Research International, 70, pp. 55-634.

14. Randhir R., Lin Y.T., Shetty K. (2004) Stimulation of phenolics, antioxidant and antimicrobial activities in dark germinated mung bean sprouts in response to peptide and phytochemical elicitors, Process Biochemistry, 39 (5), pp. 637-646.

15. Doblado R., Frías J., Vidal-Valverde (2007), Changes in vitamin C content and antioxidant capacity of raw and germinated cowpea (Vigna sinensis var. carilla) seeds induced by high pressure treatment, Food Chemistry, 101 (3), pp. 918-923.

16. Świeca M. (2015), Elicitation with abiotic stresses improves pro-health constituents, antioxidant potential and nutritional quality of lentil sprouts, Saudi Journal of Biological Sciences, 22, (4), pp. 409-416.

17. Dicko M. H., Gruppen H., Traoré A. S., J. H. van Berkel W., G. J. Voragen A. (2005), Evaluation of the Effect of Germination on Phenolic Compounds and Antioxidant Activities in Sorghum Varieties, Journal of Agricultural and Food Chemistry, 53, pp. 2581-2588.

18. Sun T., Powers J. R., Tang J. (2007) Evaluation of the antioxidant activity of asparagus, broccoli and their juices, Food Chemistry, 105, pp. 101-106.

19. Ivanova V., Yasinska I. (2013), Antioxidant activity of extracts from plants growing in Ukraine, Acta facultatis studiorum humanitatis et naturae universitatis presoviensis. Natural sciences. Biology-Ecology, 42, pp. 98-104.

20. (2004), Guide of biologically active food additives quality control and safety. Federal Center for Sanitary Inspection Ministry of Health of Russia, Moscow, pp. 69-82.

21. Brand-Williams W., Cuvelier M. E., Berset C. (1995), Use of a free radical method to evaluate antioxidant activity, LWT - Food Science and Technology, 28 (1), pp. 25-30.

22. (1990) AOAC. Official methods of analysis (15th ed.), DC:Association of Official Analytical Chemists, Washington.

23. Gharachorloo M., Tarzi B. G., Baharinia M., Homan Hemaci A. (2012), Antioxidant activity and phenolic content of germinated lentil (Lens culinaris), Journal of Medicinal Plants Research, 30 (6), pp. 4562-4566.

24. Shetty, K. (2004), Role of proline-linked pentose phosphate pathway in biosynthesis of plant phenolics for functional food and environmental applications: a review, Process Biochemistry, 39 (7), pp. 789-804.

25. Śsieca M., Gawlik-Dziki U., Kowalczyk D., Złotek U. (2012), Impact of germination time and type of illumination on the antioxidant compounds and antioxidant capacity of Lens culinaris sprouts, Scientia Horticulturae, 140, pp. 87-95. 